\title{
CONSUMPTION BASKETS AND COST OF LIVING IN SOUTHERN LATE COLONIAL BRAZIL: RIO GRANDE, 1772-1823
}

\author{
JULIO DJENDEREDJIAN \\ Universidad de Buenos Aires/Conicet ${ }^{\mathrm{a}}$ \\ JUAN LUIS MARTIRÉN \\ Universidad de Buenos Aires/Conicet ${ }^{\mathrm{b}}$
}

\begin{abstract}
This paper examines the cost of living and evolution of welfare ratios among urban workers in Rio Grande's vila, the main commercial enclave of the southern Portuguese dominions in America. From diverse sources (military and hospital expenditure accounts, merchant credit bills from probate inventories), we build different consumption baskets to calculate their cost in seven benchmark years: 1772, 1792, 1802, 1809, 1816, 1819 and 1823. The evolution of cost of living shows a consistent upward trend during the period, which, however, does not substantially affect welfare ratios. In order to build regional comparisons, we follow Allen's methodology (2001) to estimate welfare ratios of skilled and unskilled workers in Rio Grande, Buenos Aires and Montevideo. The results of using this approach could be useful to adjust the methodology for further international comparisons.
\end{abstract}

Keywords: living standards, consumption baskets, welfare ratios, late colonial Brazil, Rio de la Plata

JEL codes: J31, N16, N96

\footnotetext{
${ }^{\text {a }}$ Instituto de Historia Argentina y Americana «Dr. Emilio Ravignani». juliodjend@yahoo.com.ar

b Instituto de Historia Argentina y Americana “Dr. Emilio Ravignani”. jlmartiren@hotmail.com
} 


\section{RESUMEN}

El artículo examina la evolución del costo de vida y de los niveles de bienestar de los trabajadores urbanos en la vila de Río Grande, el principal enclave comercial de los dominios meridionales portugueses en América. A partir de diversas fuentes (cuentas de gastos militares y hospitalarios, y cuentas privadas tomadas de inventarios post-mortem), se construyen diferentes canastas de consumo y se calcula su valor monetario en distintos momentos del período analizado. Los resultados muestran un encarecimiento constante del costo de vida, que es acompañado en general por incrementos en el nivel de salarios, sobre todo de trabajadores con menor calificación. Establecemos asimismo comparaciones regionales, siguiendo la metodología propuesta por Robert Allen (2001) para estimar la evolución del poder de compra de los trabajadores calificados y no calificados en Rio Grande, Buenos Aires y Montevideo. Esta estrategia y sus resultados pretenden discutir y mejorar esa metodología para realizar comparaciones internacionales.

Palabras clave: niveles de vida, canastas de consumo, poder de compra, Brasil tardocolonial, Río de la Plata

«The conservation of Public Health depends mainly on good quality food, and meat being a food of first necessity, and the most commonly consumed; needs a lot of caution to be distributed to the public.» Luiz Pelazzy, Health Chief Guard, Vila de Rio Grande, 5 November 1824 $^{1}$

\section{INTRODUCTION}

The words of the official in charge of public health of Rio Grande-the main Atlantic port of southern Brazil in the early 1820s-are eloquent about the emblematic place that fresh meat occupied in the local daily diet. It was not only the cheapest protein source in this region, but also a critical food supply. This was an unusual phenomenon in late colonial Brazil; as a result, Rio Grande became an especially interesting case to analyse $^{2}$. It also shares common features with the nearby Rio de la Plata

\footnotetext{
${ }^{1}$ Arquivo Histórico do Rio Grande do Sul (AHRS), Autoridades Municipais, Maço A-MU-167, Cámara Municipal de Rio Grande. Own translation.

2 Dry meat (charque), with a farinaceous (manioc or corn), and some linen for clothing, made up the basic scheme of popular consumption in late colonial Brazil. This was assumed by the
} 
provinces, which makes it particularly attractive for a comparative approach $^{3}$. Geographical proximity, geopolitical importance, a similar factor endowment and abundance of livestock, had given the Rio Grande Captaincy and its neighbours an undeniable common imprint.

The study of consumption baskets and food supply markets in the $18^{\text {th }}$ and $19^{\text {th }}$ centuries has already been addressed by the Brazilian historiography, especially for large urban centres such as Rio de Janeiro and Salvador de Bahia (Lobo et al. 1971; Johnson 1973; Mattoso 1973; Barickman 2003). However, little is known about this issue in the southernmost regions of the country, characterised by the previously mentioned peculiarities. Thus, we aim to fill this gap through the analysis of the vila of Rio Grande, a strategic enclave for the Portuguese Crown, and the main urban core of a growing hinterland between 1780 and $1820^{4}$.

Despite the promising results achieved by the academic literature on colonial Latin America in recent years, there is a need to enhance our knowledge, as well as to stress the critical differences with the consumer structures of Europe or North America, which have been studied in more depth ${ }^{5}$. The contribution of this paper lies not only in presenting the composition and cost of local consumption baskets, but also in analysing the feeding patterns of the lowest income groups of the population in a slave economy. In other words, it allows us to study the hierarchical determinants of the local diet, and their impact on relative production costs, as well as on price cycles.

The article is divided into three parts. The first one focuses on the composition of local food baskets. It seeks to identify the kinds of food consumed in Rio Grande, to estimate their quantities and caloric weight. Based on hospital sources and public sector accounts, this section presents three types of consumption baskets used at that time. Following these baskets' composition, we also elaborate 'Respectable' baskets and 'Bare Bones' baskets (BBB), adapting the caloric intake to the methodology proposed by Allen (2001). Once the consumption patterns have been identified, the second part will focus on the cost of living between 1772 and 1823. For this purpose, we present evidence about the monetary cost of each basket

officials (report of the Viceroy of Brazil, in Arquivo Histórico Ultramarino, Lisbon, Rio de Janeiro, Caixa 72, doc 6614, cit. in Rodrigues (2017) and Barickman (2003, p. 89)).

${ }^{3}$ Literature on living standards in Late Colonial and Post independent Rio de la Plata is abundant. See Johnson (1990), Arroyo Abad et al. (2012), Djenderedjian and Martirén (2015), Moraes and Thul (2017), Frid (2017), Gelman and Santilli (2018).

${ }^{4}$ A historiographical renovation in the last two decades has offered new insights into the economy and society of Rio Grande during the colonial period. Some of the most outstanding works are: Osório (1999), Kühn (2006), Gil (2009). Socio-productive and demographic data for the period under analysis in Medeiros dos Santos (1984).

${ }^{5}$ For Latin America, in addition to the above-mentioned cases on the Rio de la Plata, see also Dobado and García Montero (2010), Challú and Gómez Galvarriato (2015), Dobado (2015). 
in seven benchmark years (1772, 1792, 1802, 1809, 1816, 1819 and 1823). We also estimate the total annualised cost of the BBB and Respectable baskets (which include foods and extras). The dataset is crossed with salary evidence of carpenters and construction workers with different skills (officials and unskilled labourers or serventes). This strategy allows us to measure the impact of inflation cycles and to study the changes in workers' standards of living using Allen's Welfare Ratio (WR) approach. Finally, we present a comparative analysis with two other cities in the region: Buenos Aires and Montevideo.

We use several sources to build up the evidence: merchants' account bills and invoices from probate records; account ledgers from the Provedoria and the warehouses of the Real Fazenda of the Vila of Rio Grande; accounts of the Intendencia da Marinha, the Military Hospital, the local penitentiary and the Comandancia Militar da Capitania do Rio Grande. Specific details on these sources and methods are shown in the Appendix (Data Sources section).

\section{BUILDING THE BASKET IN LATE COLONIAL SOUTH BRAZIL: COMPOSITION AND CALORIC INTAKE}

One of the foremost difficulties involved in measuring living standards in pre-statistical times is to build reasonable consumption baskets. Although it is a fairly simple task to identify the main staple foods, serious problems arise when estimating specific proportions or quantities. This is due to the fact that depending on the purchasing power of the individual, or on their ethnic or social class group (an important point in a strongly hierarchical society, as was the case of Rio Grande), the amount or kind of each food could dramatically change, not to mention cultural or age constraints. Namely, an accurate determination of the type and quantity of goods available is vital to estimate the caloric content and cost of a basket and subsequently to make inferences about the subsistence level of a person or family group.

To this end, sources derived from charitable institutions (asylums, hospitals, religious communities), mendicants (convents) or public or military (hospitals, prisons) have offered quite useful results to the literature (Gelman and Santilli 2015a, 2016, 2018; Moraes and Thul 2017). However, some precautions are required. For example, hospital diets were determined by the medical practices of the time, and as they had a therapeutic role, they included foods of high relative value, better quality or not commonly consumed by healthy people (poultry, e.g.). Moreover, in highly hierarchical societies, the consumption of religious communities could only represent the daily diet of very small groups of the population, 
leaving a large part of the population out of the analysis, particularly those ethnically or economically segregated.

As we intend to represent the social and ethnically segmented consumption baskets, we are combining two types of documents: expense bills of the Military Hospital of Rio Grande and rations' records of public and private workers, prisoners and Azorean residents. The first one is quite a valuable source, which includes monthly data on the expenditures made between 1792 and 1803. Although these records only cover 12 years of the period under analysis, they provide a very clear picture of consumption patterns and of the elasticity of the food purchases. Having processed all the monthly entries of each item, we found that fresh meat, wheat bread, manioc flour (farinha, hereafter), rice and sugar monopolised the food purchases and the caloric intake ${ }^{6}$. However, their relative weight varied in relation to price fluctuations. This evidence allows us to know the strategies developed by the hospital staff to change diet components, in order to save costs in case of inflation.

As previously mentioned, meat was very cheap and abundant ${ }^{7}$. It provided food security in Rio Grande, since cattle was not only an economic asset but also a strategic resource, carefully protected and moved to safer places when wars broke out. This abundance constituted a reservoir for times of scarcity, especially during agrarian crisis. Even in the course of the worst droughts, while cereal prices soared, the meat supply could increase, as more animals were sent to markets due to their breeder's concerns about their survival in a context of grass shortage. Although ranches in Rio Grande were not as large as those in the neighbouring provinces of the Banda Oriental or Entre Ríos, nor were their herds so overabundant, cattle ranching was always one of the main rural activities (Osório 1999). In short, there is a sharp similarity with the cases of Buenos Aires and Montevideo, where the weight of fresh meat in the population's daily diet has been already stressed by the literature (Johnson 1990; Moraes and Thul 2017; Gelman and Santilli 2018).

\footnotetext{
${ }^{6}$ See Table A1. Additionally, Figure A1 shows the general expenses incurred. Food is more important throughout the period.

7 Luccock, Saint-Hilaire or Isabelle, three of the best known chroniclers who travelled or lived in Rio Grande during the first decades of the $19^{\text {th }}$ century, agreed that meat, accompanied by farinha, was the main food of the population. Bread, on the other hand, was less common in the lower classes, although until 1822 Rio Grande was a large producer of wheat. According to Saint-Hilaire: «Each man's ration is four pounds of meat a day [1.84 kilograms], and they only feed on the fatter, fleshier parts of the animal. The soldiers of the region have easily become accustomed to such a regime, which is in fact little different from their usual way of life; notwithstanding the emergence of diseases due to excessive carnivorous feeding, mainly dysentery, among the Paulists [from São Paulo], more accustomed to beans and flour than to meat.» (Saint Hilaire 2002 [1887], p. 52). Own translation
} 
The hospital expense records show that, when bread prices went up, meat and, to a lesser extent, farinha operated as partial substitutes (see Table A1). It is significant that according to this source, between 1792 and 1803 , bread prices were constant (always at 40 reis the unit of 0.575 kilograms), so we assume that price was regulated ${ }^{8}$. Thus, probably this drop in bread purchases is due to an increase in its price, which per unit was not registered at the source; perhaps because the supplier was under contract and obliged not to break the laws in force. To compensate for this fall, in their purchases of food, officials not only bought more meat, but also farinha and rice, looking to roughly balance the total caloric intake.

This argument is reinforced when analysing the weight of each food in relation to the monetary expenditures, supporting the idea that substitution was due to price variations. At the same time, the role of rice in hospital spending was interesting, since its high value in monetary terms did not translate into a proportionally high caloric intake (see Table A1). Evidently, rice operated as a leading carbohydrate substitute for bread, even exceeding in amount of what was spent on meat and farinha. In this sense, it needs to be explained why the purchases included rice, not relying only on farinha, the cheapest alternative. This was probably due to cultural or mercantile aspects, since rice was probably more widely available at the local level than farinha, imported from other Brazilian Atlantic ports (at least during part of this period).

In sum, we have developed a fairly comprehensive overview of the Rio Grande's Hospital basket at the dawn of the $18^{\text {th }}$ century. However, the food quantities have yet to be estimated, both for higher social groups (those theoretically represented by hospital consumption) and the lower ones. Therefore, we will present below (Table 1) three alternatives to real baskets, which would characterise them more accurately.

The first basket was calculated from the average quantity of food consumed by hospital patients during the first quarter of $1803^{9}$. Considering the broadness of supply and the relatively high consumption of each good, we assume that this diet would represent upper classes' consumption patterns. It also coincides, in general terms, with the percentages of the hospital for the whole period, calculated in Table A1 of the Appendix. Even though these diets were in fact prescribed at that time, they should not be taken restrictively to build consumption baskets. We must consider that this hospital was a public institution, hence not only did it offer more

\footnotetext{
${ }^{8}$ We present a bread prices series in Table A3.

${ }^{9}$ Fortunately, the source details day by day the amount of food distributed and total number of inpatients, discriminating between serious (to whom they only administered chicken broth) and mild/medium (to whom a wider arrange of foods was given). Data taken from AHRS, Fazenda, Maço 63, Despeza diaria feita no Hosp. ${ }^{\text {al }}$ Real Militar da $V^{a}$. Do Rio Grande nos 3 mezes de Janeiro a Março, year 1803.
} 
TABLE 1

DAILY CONSUMPTION BASKETS IN RIO GRANDE, 1772-1823

\begin{tabular}{|c|c|c|c|c|c|c|}
\hline & Hospi & & & & & \\
\hline & $\begin{array}{l}\text { Average } \\
\text { January-Mar }\end{array}$ & h 1803 & Free urban & orker & $\begin{array}{l}\text { conditioned } \\
\text { worker }\end{array}$ & rban \\
\hline Product & $\begin{array}{l}\text { Equivalence } \\
\text { in Kgs. }\end{array}$ & Calories & $\begin{array}{l}\text { Equivalence } \\
\text { in Kgs. } \\
\end{array}$ & Calories & $\begin{array}{l}\text { Equivalence } \\
\text { in Kgs. }\end{array}$ & Calories \\
\hline Fresh Meat & 0.92 & 1,316 & 0.92 & 1,316 & 0.92 & 1,316 \\
\hline Farinha & 0.31 & 1,123 & 0.57 & 2,041 & 0.37 & 1,347 \\
\hline Rice & 0.22 & 283 & - & - & - & - \\
\hline Bread & 0.38 & 1,006 & - & - & - & - \\
\hline Sugar & 0.06 & 224 & - & - & - & - \\
\hline Total calories & & 3,952 & & 3,357 & & 2,663 \\
\hline
\end{tabular}

Source: Computed with data from: AHRS, Fazenda, Maço 63, Despeza diaria feita no Hosp. ${ }^{\text {al }}$ Real Militar da V ${ }^{a}$ Do Rio Grande nos 3 mezes de Janeiro a Março, year 1803; See Arquivo Nacional, Códice 104, Vol. 2, fols. 222; AHRS, Fondo Fazenda, Año 1800, Tomo 57, Año 1800, Plano das Prassas empregadas na olaria que resseberam municio de farinha e carne; AHRS, Fundo Fazenda, Tomo 74, Año 1806, Relação das Pessoas que unicamente devem vencer Municio de Carne e Farinha pela Real Fazenda do 1ro de Janeiro do anno fucturo de 1806 em diante; AHRS, Fundo Fazenda, Maço 522, Año 1835, Despeza com o alimento dos presos pobres da cadeia civil desta Villa.

calories than an ordinary daily diet, but it is also probable that its expenditures did not fully reflect the impact of large price fluctuations on the general population.

Based on the above-mentioned rations' records, we present two other model baskets, applicable to urban workers. The first one was for free white/mestizo, and the second for slaves/Indians. This division arises from the differences in wages and rations that we have found among these groups, a common feature of a deeply segmented society, not only in the legal or ethnic status of the population, but also in food intake and job positions/earnings available in the labour market. With these diets, we aim to present a more accurate view of the local consumption patterns for the lowest income groups, which are essentially the most significant variable in the analysis of living standards. The only real difference between these two «actual» baskets was the amount of farinha. While free urban workers received a tenth of a quarter of alqueire, the Indians or slaves had their share reduced to $2 / 3$ of a tenth, according to our sources. We have also found differences between the wages of slaves and Indians hired ${ }^{10}$.

10 Indians and slaves usually received a payment, although it was a mere fraction of the salary earned by a free worker. To set data of urban workers' diets, we used several sources. For the decade 
Thus, we have two baskets that are very close to the total daily recommended caloric limit for male adults undergoing moderate/intense work $(3,000$ calories a day). The first one exceeds it slightly, and the other is a little below. Nevertheless, the caloric content does not imply an accurate calculation since, as stressed in the Appendix methodological note, meat presents large differences in terms of calories according to the animal in question, cutting and discarding.

Having settled the composition and caloric content of Rio Grande's daily consumption patterns, we calculated two baskets, each reaching a total of only 1,941 calories, based upon Allen's methodology (Allen 2001; Allen et al. 2012). Both baskets not only include food, but also other basic consumer goods such as cleaning, lighting and fuel (Table 2).

The baskets shown in Table 2 present the consumption structure of individual subsistence baskets (Respectable and $\mathrm{BBB}$ ). In order to calculate the estimates of living standards and presenting international comparisons, the methodology proposed by Allen annualises the total cost and multiplies it by a theoretical family group (3.15 people) (Allen 2001, p. 427). In the next section, we will analyse the evolution of its cost over the period under review.

\section{MEASURING LIVING STANDARDS: WELFARE RATIOS AMONG URBAN WORKERS}

Once the baskets for the period under analysis have been identified, we then calculated their monetary cost (Table 3 ). As it is very difficult to build comprehensive series for each year, we have chosen those years when prices for all basket products were available. There are seven benchmark years between 1772 and 1823, an adequate amount of evidence, although we were not able to complete data for the 1780s.

Table 3 offers the evolution of the three types of real consumption baskets presented in Table 1, and the Respectable baskets and BBB, based on Allen $(2001)^{11}$. It shows the evolution of food costs in different groups of

\footnotetext{
of 1770, we have taken the rations granted by the Capitania of Rio Grande to the inhabitants of the Azores Islands that left Colonia del Sacramento after the Treaty of San Ildefonso signed by the Iberian crowns. For the decades of 1790, 1800 and 1810 we have taken three sources, in all cases coinciding: the rations offered to workers in a brick kiln (segmented according to native and Indian workers) corresponding to the year 1800; and the rations granted by the Real Fazenda to the military and public employees for the year 1804 . We extended these proportions to the entire period studied. Although it does not cover our period and does not correspond to Rio Grande, we have also considered data on prisoners' diet at the Rio Pardo jail for the year 1835. We thank Luciano Costa Gomes for providing us with the information and documentation regarding the rations for the inhabitants of the Azores Islands.

${ }^{11}$ It is important to note that the evidence presented in Figure 1 corresponds only to the daily value of a food basket. The non-food items (described in the Table 2) and the total family cost will only be computed to estimate the Welfare Ratio.
} 
TABLE 2

RESPECTABLE AND BARE BONE BASKETS IN RIO GRANDE, 1772-1823*

\begin{tabular}{|c|c|c|c|c|c|c|c|c|}
\hline Food & & & & Daily qu & tities & & & \\
\hline & & Respec & able & & & Bare Bor & basket & \\
\hline Product & $\begin{array}{l}\text { Equivalence } \\
\text { in } \mathbf{~ K g}\end{array}$ & Calories & $\begin{array}{l}\text { Calories } \\
\text { share }\end{array}$ & $\begin{array}{l}\text { Spending } \\
\text { share }^{1}\end{array}$ & $\begin{array}{l}\text { Equivalence } \\
\text { in } \mathbf{~ K g}\end{array}$ & Calories & $\begin{array}{l}\text { Calories } \\
\text { share }\end{array}$ & $\begin{array}{l}\text { Spending } \\
\text { share* }\end{array}$ \\
\hline Fresh meat & 0.45 & 646 & $33 \%$ & $10 \%$ & 0.53 & 761 & $39 \%$ & $30.6 \%$ \\
\hline Farinha & 0.15 & 551 & $28 \%$ & $8 \%$ & 0.33 & 1,180 & $61 \%$ & $42.9 \%$ \\
\hline Rice & 0.11 & 139 & $7 \%$ & $24 \%$ & - & - & - & \\
\hline Bread & 0.19 & 494 & $25 \%$ & $21 \%$ & - & - & - & \\
\hline Sugar & 0.03 & 110 & $6 \%$ & $10 \%$ & - & - & - & \\
\hline Total foods & 0.93 & 1,941 & $100 \%$ & $73.5 \%$ & 0.86 & 1,941 & $100 \%$ & $73.5 \%$ \\
\hline Extras & & & & Annual q & ntities & & & \\
\hline & Quantity & Unit & $\begin{array}{l}\text { Spending } \\
\text { share }^{2}\end{array}$ & & & & & $\begin{array}{l}\text { Spending } \\
\text { share }^{1}\end{array}$ \\
\hline Cotton & 5 & Meters & $5 \%$ & & & & & $5 \%$ \\
\hline Soap & 2.6 & Kilograms & $2 \%$ & & & & & $2 \%$ \\
\hline Candles & 2.6 & Kilograms & $3 \%$ & & & & & $3 \%$ \\
\hline Fuel (firewood) & 280 & Kilograms & $16.5 \%$ & & & & & $16.5 \%$ \\
\hline
\end{tabular}


TABLE 2 (Cont.)

\begin{tabular}{|l|l|l|l|l|l|l|l|l|}
\hline Food & \multicolumn{6}{|c|}{ Daily quantities } \\
\hline & \multicolumn{5}{|c|}{ Respectable } & \multicolumn{3}{c|}{ Bare Bones basket } \\
\hline Product & $\begin{array}{l}\text { Equivalence } \\
\text { in Kg }\end{array}$ & Calories & $\begin{array}{l}\text { Calories } \\
\text { share }\end{array}$ & $\begin{array}{l}\text { Spending } \\
\text { share }\end{array}$ & $\begin{array}{l}\text { Equivalence } \\
\text { in Kg }\end{array}$ & Calories & $\begin{array}{l}\text { Calories } \\
\text { share }\end{array}$ & $\begin{array}{l}\text { Spending } \\
\text { share* }\end{array}$ \\
\hline Total extras & & & $26.5 \%$ & & & & & $26.5 \%$ \\
TOTAL & & $\begin{array}{l}200 \% \\
10 \%\end{array}$ & & & $100 \%$ \\
\hline
\end{tabular}

${ }^{1}$ Spending percentages were calculated from average market prices of seven benchmark years (1772, 1792, 1802, 1809, 1816, 1819 and 1823$)$. Data sources in Appendix.

${ }^{2}$ Estimations from Moraes and Thul, 2017, p. 16

*Since we did not have prices for firewood for the entire period, we took the percentages from Moraes and Thul (2017, p. 16). This is a frequent problem in many of the studies that opted for Allen's method, especially for comparative approaches on Latin America. Although we had an average price for textiles and candles for Rio Grande taken from the hospital sources (1792-1803), we preferred to use Montevideo spending shares (which are in fact similar to those found by Gelman and Santilli for Buenos Aires), as we have not found reliable data for the quantity and cost of firewood. Considering that the purpose of this methodological exercise is to compare with other places, this seems to be the most reasonable methodological option. Of course, this is debatable in terms of historical accuracy.

Source: Calculated with data from Table 1 and Moraes and Thul (2017, p. 16) 
TABLE 3

FOOD BASKETS COST EVOLUTION IN RIO GRANDE, AT CURRENT PRICES (IN REIS)

\begin{tabular}{|l|c|c|c|c|c|c|r|}
\hline & $\mathbf{1 7 7 2}$ & $\mathbf{1 7 9 2}$ & $\mathbf{1 8 0 2}$ & $\mathbf{1 8 0 9}$ & $\mathbf{1 8 1 6}$ & $\mathbf{1 8 1 9}$ & $\mathbf{1 8 2 3}$ \\
\hline Bare Bones & 13 & 15 & 14 & 22 & 19 & 27 & 35 \\
$\begin{array}{l}\text { Ethnic or legally } \\
\quad \text { conditioned } \\
\text { urban worker }\end{array}$ & 18 & 19 & 18 & 28 & 36 & 39 & 53 \\
$\begin{array}{l}\text { Free urban } \\
\quad \text { worker }\end{array}$ & 23 & 26 & 24 & 38 & 44 & 48 & 62 \\
$\begin{array}{l}\text { Respectable } \\
\begin{array}{l}\text { Hospital avg. } \\
1803\end{array}\end{array}$ & 39 & 37 & 52 & 48 & 62 & 60 & $\mathrm{n} / \mathrm{d}$ \\
& 99 & 76 & 114 & 104 & 133 & 129 & $\mathrm{n} / \mathrm{d}$ \\
\hline
\end{tabular}

Source: Tables 1 and 2, and sources cited in Appendix.

Rio Grande's society between 1772 and 1823. An inflationary trend in local currency is evident, although quite divergent, mainly due to the different composition of baskets. For example, in the 1770s, the hospital basket's value started at a relatively high level, because Rio Grande was under Spanish dominion (after Pedro Cevallos's invasion in 1762, only overthrown by Portuguese troops in 1776). For this reason, the population was dispersed among other freguesias, or established new settlements some kilometres north. This affected food supply from other regions, particularly imported rice.

The following benchmark year, 1792, shows the effect of relative political and economic stability since the end of the 1770s. There is a steady drop in the price of the basic hospital basket. However, at the turn of the century, food prices began to rise for different reasons. By 1802, higher costs were again basically due to rice prices. As early as 1809, farinha and to a lesser extent, meat was responsible for the rise in prices. However, in the following years, a new tax on meat ( 5 reis per pound), imposed by the Portuguese Crown, had a major impact on the cost of living. We have no evidence of the consequences of this new tax in other Brazilian regions, but in Rio Grande, the rise was sharp due to the importance of meat in the basket. Consequently, the inflation impact was evident, even when it was alleviated by a small fall in rice and farinha prices. The price of meat continued its upward trend in 1819, but the Respectable basket's total cost was practically the same as in the previous year because the price of rice experienced a very steep fall. We could not include the 1823 Respectable basket's cost, as the price of bread was not available. The importance of meat as a strategic consumption good affecting all groups is clear, although with a stronger impact among the lower income population. 
This is particularly clear when considering the subsistence baskets, that is, those that we identified as representative for different categories of the lowest group of urban workers. It depicts juridical and ethnical conditions, using available information on consumption for each group, considering thus not only income, but also social constraints. It is difficult to fully reflect all the complexities of a society composed of slaves, wealthy contratadores and a wide array of family arrangements. However, the basic components of subsistence for each level are generally shown.

Two main aspects need to be stressed. The first one is related to the consistent increases in the cost of living from 1809. Besides the impact of the previously mentioned tax on meat (which will only be evident from 1816 onwards), prices experienced an upward trend at least since as early as 1802. Nonetheless, the cost of living remained low, as throughout the period, these baskets were easily attainable even by the lower levels of salaried workers. This was due to the extremely low price of meat, showing its strategic role as a balancer among the basket's components. In turn, fresh meat played a key role in an asymmetric food price structure, where price changes in one of the main components of the basket did not necessarily affect the others. Available accounts, which included data on slaves' food prices, show strong coincidences. For example, probate inventories of Manoel Jesus Da Costa and Felipe J. de Andrade registered daily food expenses for their slaves of around 60 reis between 1820 and 1824. This figure is very similar to the actual baskets' costs in our tables ${ }^{12}$. It should also be noted that the BBB follow the same inflationary path as the «real» baskets, meaning that the BBB should accurately represent the evolution over time of actual costs of living. This is relevant, because even if we accept the «artificial» nature of the welfare ratios made upon Allen's (2001) methodology, these indicators must provide a realistic approach to living standards in the past, particularly in the long run, when key features of the food economy structure are shown ${ }^{13}$.

Was this evolution of the basic consumption basket followed by changes in workers' wages? Qualitative sources show that access to basic food for a young family group (i.e. two adults in their 20s) was relatively easy among workers in the lower level of the social structure. In the words of an English merchant about Rio Grande slave workers:

12 APERS, Inventários, Box 005.0586, Comarca de São Pedro do Rio Grande e Santa Catarina, Orphãos e Provedoria, probate inventory of Manoel Jesus da Costa; and Box 005.0588, Comarca de São Pedro do Rio Grande e Santa Catarina, Orphãos e Provedoria, probate inventory of Felipe J. de Andrade.

${ }^{13}$ Particularly in major crises, when the symmetric or asymmetric nature of food provision is evident. 
FIGURE 1

RESPECTABLE AND BBB TOTAL COST AT CURRENT PRICES AND NOMINAL INCOME OF MASONS AND CARPENTERS IN RIO GRANDE, 1772-1823. ANNUAL VALUES, IN LOCAL CURRENCY (REIS).

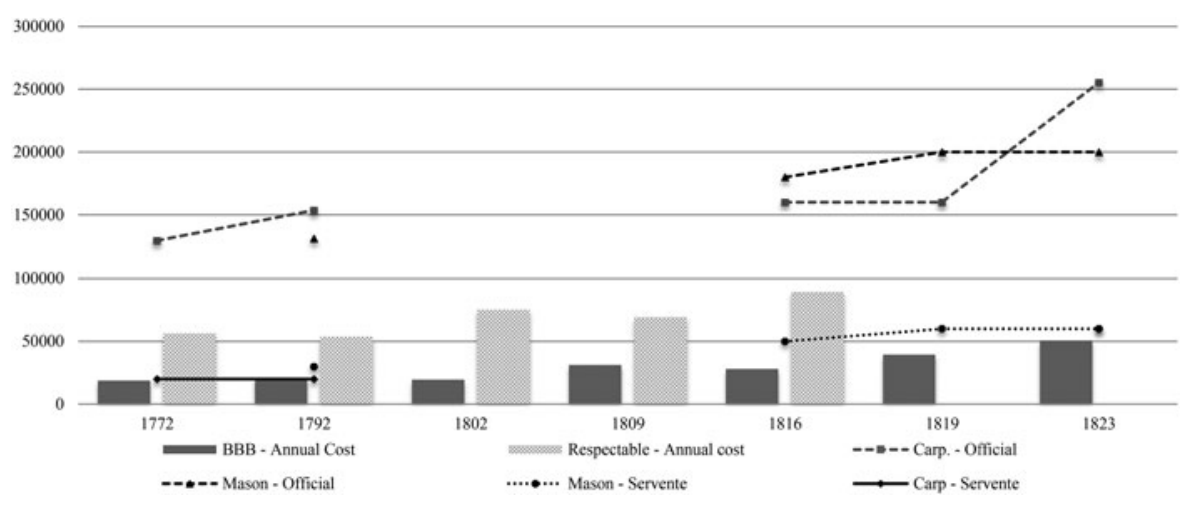

Source: See data sources in Appendix.

«The blacks may, possibly, and doubtless so, think a little labour excessive. Yet such person can earn, in an hour, two vintems [40 reis], about four-pence, which is sufficient to provide them food for a day. When one of them is seen lounging about, and asked to undertake any job, the common reply is-"I have already earned». It may be said, indeed, that there is hardly a poor person in the town, nature having placed the necessaries of life within the easy reach of all; and wanting but little, they enjoy that little in a degree which might excite the envy of the ambitious and restless.» (Luccock 1820, p. 202)

Leaving aside prejudices or subjectivity of the observer, this testimony shows once again that fresh meat was an inexpensive and abundant subsistence good in Rio Grande. The excellent ratio between meat's price and its nutritional value granted high subsistence levels even for lowincome workers. Likewise, quantitative data also point in this direction, as can be seen in Figure 1 which confirms the high standards of living of Rio Grande. Following Allen's methodology, the bars show the annualised family cost of the baskets, between 1772 and 1823 . The lines account for the nominal annual income of construction workers, with different degrees of qualifications. Collected sources from bills of the Real Fazenda and probate inventories offer daily wages of urban workers, mostly carpenter's assistants and masons, generally in three categories: Master, Official and Servente ${ }^{14}$. Unfortunately, there is not enough data to build Masters

\footnotetext{
14 Respectively, for the first three categories: «Maestro», "Oficial» and «Aprendiz».
} 
TABLE 4

CARPENTERS AND MASONS WELFARE RATIOS EVOLUTION USING ANNUAL RESPECTABLE AND BARE BONES BASKETS (1772-1823)

\begin{tabular}{|l|l|l|l|l|l|l|l|l|l|l|}
\hline & \multicolumn{9}{c|}{ BBB } & \multicolumn{6}{c|}{ Respectable } \\
\hline & $\mathbf{1 7 7 2}$ & $\mathbf{1 7 9 2}$ & $\mathbf{1 8 1 6}$ & $\mathbf{1 8 1 9}$ & $\mathbf{1 8 2 3}$ & $\mathbf{1 7 7 2}$ & $\mathbf{1 7 9 2}$ & $\mathbf{1 8 1 6}$ & $\mathbf{1 8 1 9}$ & $\mathbf{1 8 2 3}$ \\
\hline Carpenters \\
\begin{tabular}{|l|l|l|l|l|l|l|l|l|l|} 
Officials \\
Serventes
\end{tabular} & 6.88 & 7.32 & 5.71 & 4.05 & 5.02 & 2.29 & 2.86 & 1.79 & 1.76 & - \\
Masons & 0.95 & 1.02 & - & - & 1.18 & 0.37 & 0.27 & - & & - \\
Officials & - & 6.26 & 3.54 & 3.93 & 3.93 & - & 2.44 & 2.01 & 2.20 & - \\
Serventes & - & 1.43 & 0.98 & 1.18 & 1.18 & - & 0.40 & 0.56 & 0.66 & - \\
\hline
\end{tabular}

Source: Calculated with data from Table 2.

series, and consequently, we have only included examples from the middle (officials) and the lowest group (serventes/unskilled labourers). Although there are information gaps, we consider that these two categories represent both workers with some qualifications and unskilled ones. The annual income was calculated from daily wages multiplied by 250 working days per year (Allen 2001, p. 427).

The evidence confirms again the inflationary cycle, particularly after 1816 in Respectable baskets (which included a wider and more varied range of goods and was therefore subject to price variations). However, it can also be seen that wages generally matched inflation, even in the least qualified groups. The welfare ratios covered subsistence levels in almost all benchmark years, as can be seen in Table 4 .

Results can be summarised in three main points. First, it is evident that all workers could reach subsistence levels throughout this period, even considering a family group of 3.15 people, as proposed by Allen. However, it must be stated that this methodology has important issues, particularly in cases such as the serventes category. As discussed in previous research (Djenderedjian and Martirén 2016), salaries, regional diets and housing had different structures in $18^{\text {th }}$-century Latin America vis-à-vis other regions of the world. Among other problems, it should be considered that in particular, monthly salary, as a category, had diverse meanings and scopes throughout the regions, as it also included some extra benefits (both in food and other supplementary goods (called 'vicios' in Spanish)). Working time was not the only thing to be paid for; a wide range of other aspects, such as loyalty, productivity or even submission, was also rewarded. Therefore, it is important to highlight that the monthly salary category is problematic to estimate real wages or living standards at that time. The relationship between masters and workers was not 
necessarily governed only by economic matters; the duties and rights of both sides should be understood under a strong moral framework, as society itself was still defined within religious beliefs and the weight of traditional corporate bodies, where only those at the head of a "great house» had the power to take decisions. Patrons, for example, should take care of a wide range of spiritual issues when dealing with their workers. They were responsible for their conduct, matching the hierarchical relationship usual in those times between persons of different "quality». Patrons' responsibilities included even completely private matters, such as their workers' ability to marry. This was so even in major cities, more suitable places for the spread of purely economic interests. Besides, as most young people did not live on their own but as dependents in great houses, salaries in the lower part of the workers' scale were not necessarily intended to maintain a whole family ${ }^{15}$. Daily wages, even considered in the context of this traditional framework, were more suitable to represent the monetary price of hours worked. On the one hand, because of the short-term contract they involved; on the other hand, since daily wages were undoubtedly less contaminated by «moral» constraints such as loyalty or others that clearly affected the long-term relationship between patrons and peons. This is why we use daily wages and not monthly salaries.

Second, it is evident that a high skill premium was in force throughout this period, implying wide margins between workers' salaries. This situation reflected a strong social and juridical segmentation, which, however, allowed income levels to be high enough for all to cover basic needs. Third, our results show a slight downward trend in Respectable baskets WR through time, particularly among qualified carpenters between 1792 and $1816^{16}$. Besides their enduring ability to purchase a consistent amount of food subsistence baskets, it is remarkable that workers experienced a clear decline in their purchasing power. This was due not only to increases in meat prices (thanks, in part, to the previously mentioned tax), but also to the fact that farinha broke, to some extent, the traditionally asymmetrical food supply structure. In this regard, it is important to mention that serventes did not experience significant losses in their purchasing power, as they were able to access practically the same number of baskets throughout the period, despite the inflationary process. This shows that, even under the double impact of the slight devaluation that affected the Brazilian currency between 1820 and 1823, and the rise in food prices, earnings (or at least daily wages) of low-income workers supported these

\footnotetext{
15 See Djenderedjian and Martirén (2016)

16 As noted earlier, unfortunately we do not have data for Respectable baskets in 1823, but considering the inflationary cycle, their WR would probably have decreased.
} 
changes well, therefore allowing people not to suffer significant changes in their living standards ${ }^{17}$.

In short, the food basket analysis provided us with some preliminary results on living standards in southern Brazil at the end of the colonial regime. Beyond subtleties on limits and the potential of hospital baskets or the different methodological issues referred to in previous pages, it is important to stress that all data and calculations show a relatively low cost of living, easily within the reach of workers at even the lowest levels of income (except slaves, for obvious reasons). Despite not including the worst part of the high inflationary cycle of the 1820s, basket coverage was widespread. These results allow us to understand better the lack of subsistence crises or food shortages even in a period when the traditionally asymmetrical food supply structure was challenged by the commoditisation of some of its components, as meat began to be widely exported as charque (Bell 1993; Berute 2011; Vargas 2016). Our results also shed light on how an extremely divided, unequal and hierarchical society was able to deal with these constraints, as low-income and young people without the support of a family were, apparently, able to survive without too many problems.

Why food prices remained at lower levels than those in the Rio de la Plata neighbours? Was the relative abundance of low-cost labour (slaves) in Rio Grande the main reason for this? In the next section, we will offer some possible explanations.

\section{A REGIONAL COMPARISON: RIO GRANDE, MONTEVIDEO AND BUENOS AIRES}

Were these characteristics unique of Rio Grande or were low food prices due to the abundance of meat a common feature in the Rio de la Plata region during this period? To answer this question, we compare Rio Grande with the other two main harbour cities studied by Gelman and Santilli (2018) and Moraes and Thul (2017): Buenos Aires and Montevideo, respectively. Both studies used the 1,941 calories (Bare Bones) basket and welfare ratios according to Allen (2001). It is important to mention that despite the utility of Allen's method, it has many problems when implemented without considering regional particularities, which can even make international comparisons fail ${ }^{18}$.

17 Long-run exchange rates of mil-reis in Moura (2010).

18 An interesting debate about this methodology can be seen in some articles published in Issue 33, vol. 1 of Revista de Historia Económica-Journal of Iberian and Latin American Economic History. See, among others, Dobado and García Montero (2010), Allen et al. (2015), Arroyo Abad et al. (2012). 
Many of this method's starting points are deeply subjective, so results can be different with minimal changes in only one variable. The River Plate region raises several considerations, particularly concerning the importance of meat in the diet since it was not only the main food, but also a strategic staple; the cheapest in relative terms. Therefore, including more or less meat in the diet can substantially change the results. This is clear in the cases of Montevideo and Buenos Aires: Moraes and Thul's (2017, p. 16) basket includes 23 per cent of calories from meat, but the corresponding figure in Gelman and Santilli's (2018, pp. 9-11) is 62 per cent. These variations resulted in significant differences affecting the total cost. This does not imply that the figures are wrong, but when dealing with comparisons, quantities of each good must be similar, or even equal, if the entire region shares a comparable consumption structure with meat being always the cheapest staple food. Using fixed baskets for a long period of time also underestimates the cross-price elasticity of some products. As can be seen in Table A1, the hospital continuously used replacement goods.

In our research, we built both baskets (Respectable and Bare Bones of 1,941 calories) following real diets found in local sources. However, when comparing with Buenos Aires and Montevideo datasets, we see that our $\mathrm{BBB}$ is extremely simple, but our Respectable Basket is similar to the Buenos Aires and Montevideo BBB. Is this a valid method? On the one hand, it is, as it deals with the particular baskets of each city. On the other hand, however, it should be acknowledged that this is not a precise comparison, which is impossible at the moment.

It is difficult to make welfare ratio comparisons when the benchmark years and occupations used are not the same. For Montevideo, Moraes and Thul (2017) offer averaged information by decades, of various kinds of construction workers and for rural and maritime occupations. Regarding Buenos Aires, the available evidence provides data on skilled construction workers («oficiales») and only one of the benchmark years, 1825 , is comparable with our evidence ${ }^{19}$. This is important when we are not sure about the comparability of local occupations. Was a servente of Rio Grande the same kind of worker as a labourer («peón») in Montevideo? Both represent the unskilled sector (and therefore the comparison is interesting), but it is difficult to appreciate the differences between them clearly, if such differences existed.

19 It is worth mentioning that Lyman Johnson (1990) calculated living standards for Buenos Aires in 1810. However, we decided not to consider his results, as the methodology used is different than Moraes and Thul (2017). Also, we have not considered research by Leticia Arroyo Abad for Buenos Aires during 1776-1820, as it is not clear which construction salaries are included, or how nominal salary series have been averaged (Arroyo Abad took data from Johnson). See Arroyo Abad et al. (2012). Critical notes on this evidence in Gelman and Santilli (2018). 
Having considered these methodological issues, we used data from baskets of both cities for comparisons with Rio Grande. Welfare ratios were calculated on the base of similar professions: for Montevideo, we considered data for unskilled labourers («peón») (Moraes and Thul 2017, p. 19), to make comparisons with the «serventes» of Rio Grande. They do not necessarily belong to the same category, as the Rio Grande serventes were mostly youngsters, probably slaves, and their earnings had a wider gap with respect to those of building officers than those existing in Montevideo between unskilled labourers and higher categories. We have also compared building officials since we have evidence for the three cities. For carpenters, information is offered for Rio Grande and Montevideo. Despite all these difficulties, we believe this is the most accurate way to make useful comparisons (Table 5).

Table 5 shows several differences, but also some similarities. It is clear that the standards of living in Rio Grande resembled more closely those of Buenos Aires than those of Montevideo, where welfare ratios were lower in all cases. The most remarkable point is, no doubt, the situation of skilled workers (building and carpenters' officials). Even though in all cases they were relatively well positioned, it seems clear that Rio Grande's welfare ratios were better than those of its neighbouring harbour cities in some years between 1770 and 1810 . It seems to be a counterintuitive result, as these cities were relatively similar areas in geography, production, society and demography. As Moraes and Thul (2017, pp. 24-25) pointed out, low Montevideo standards are probably displaying some of the problems of Allen's methodology. It does not reflect the actual conditions of food access properly, at least for not qualified workers. At that time, Montevideo and its hinterland were experiencing a strong economic expansion. Therefore, what would happen if the simpler BBB of Rio Grande was applied to Montevideo? The results would probably take a positive trend and resemble the Brazilian case. This shows how a small shift in the basket structure can radically change the welfare indicators.

Rio Grande, as previously observed, seems to be more similar to Buenos Aires, at least during the 1820s. According to Gelman and Santilli's (2018) estimations for 1825, annual earnings of a building official could purchase 3.28 BBB, while for 1823, according to our data for Rio Grande, a similar employee could reach 3.68 Respectable baskets and 5.02 BBB. If we consider that Gelman and Santilli's BBB was close (in composition) to the Respectable basket for Rio Grande, the WR levels would be very similar.

It is important to settle some preliminary hypotheses on this, apparently, higher standard of living in Rio Grande, compared to the neighbouring cities. It should be noted that the larger differences are found in the composition of the BB basket, which is much simpler in Rio Grande. As a possible explanation, we could mention that Rio Grande had a lower relative labour cost as a large share of its workers were slaves (about 30 per cent of its population were slaves vs. less than 10 per cent in Buenos 
TABLE 5

WELFARE RATIOS OF URBAN WORKERS IN THE RIVER PLATE REGION AT THE END OF THE COLONIAL PERIOD

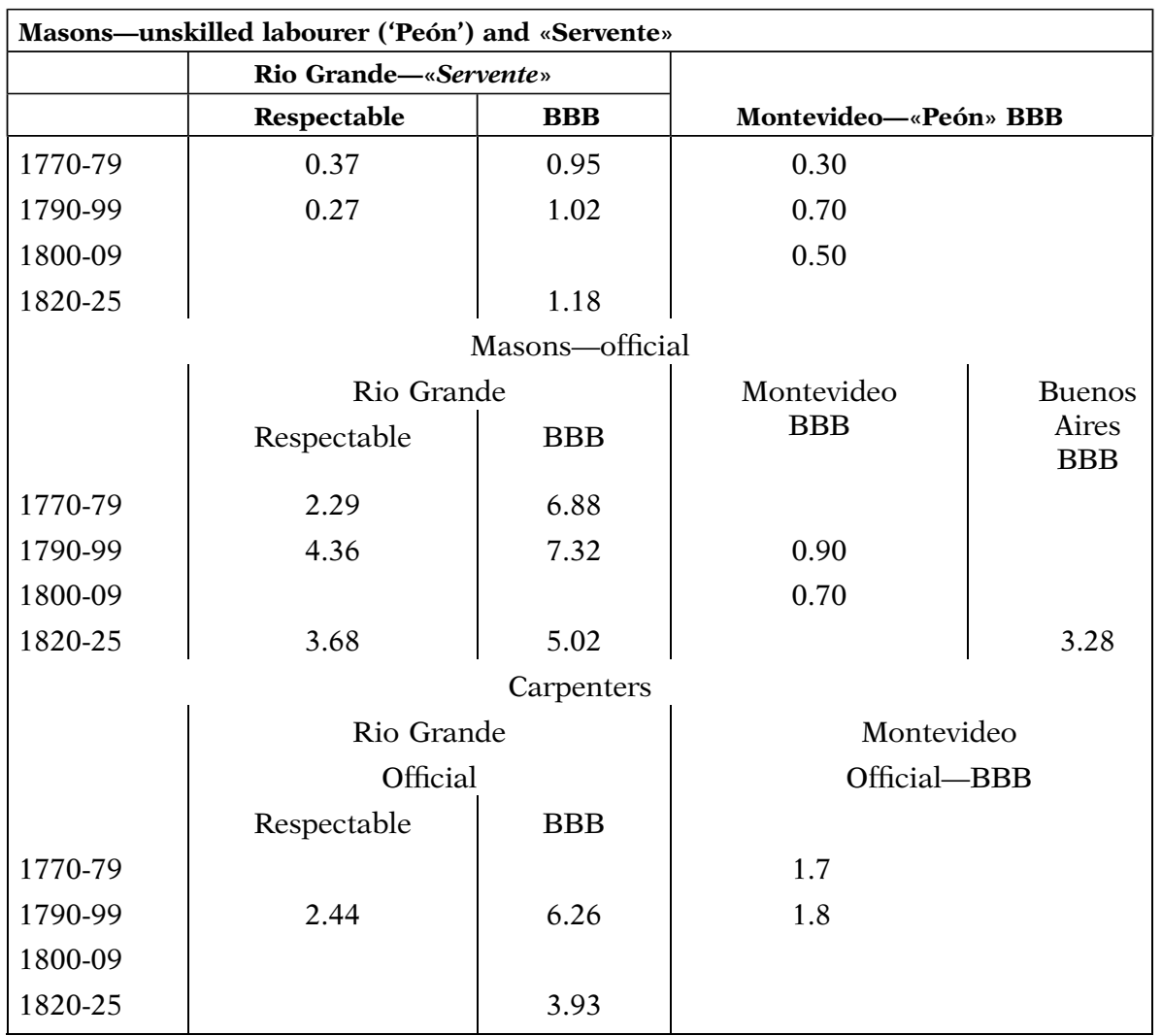

Sources: Montevideo: Moraes and Thul (2017, p. 19); Buenos Aires: Gelman and Santilli (2018, pp. 9-11). For Rio Grande, Figure 1 and Table 4.

Aires $)^{20}$. This lower cost of the main productive factor at that time probably resulted in cheaper food, both for locally produced and for imported from other Brazilian regions (as was the case of farinha). Therefore, cheaper

${ }^{20}$ According to the 1798 census, in the Parish of São Pedro do Rio Grande, there were 6,500 registered people, of whom 2,013 were slaves. In the following census of 1802, the proportion had risen to 38 per cent. See Medeiros dos Santos (1984: 35-36). These figures were similar to those of the Captaincy of Rio Grande in the same years, which ranged between 30 and 40 per cent. See Scott (2017: 624). In rural Buenos Aires and neighbouring territories, by 1800, according to Comadrán Ruiz (1969), slaves accounted for figures between 5 and 10 per cent of the total population. These figures have been confirmed by more detailed recent research, although regional variations were wide. See, for example, Banzato (2001). 
food allowed better standards of living for the free population, even though placed at the lowest social and productive levels, and consequently with the lowest incomes.

This phenomenon also contributed to lower the maintenance costs of slaves, boosting the expansion (or at least the preference) for them to fulfil labour needs (Aladren 2012). It is also remarkable, however, that the gap between skilled and unskilled workers was apparently higher in Rio Grande than in its neighbours, which points to a wider income inequality. This is not surprising if we take into account the extent to which the labour supply in Rio Grande (and in Brazil in general) relied on slaves. It was a deeply hierarchical society, in which slavery was crucial for its operation. This meant that higher categories were clearly differentiated (in several edges) from lower ones, at least more than in Buenos Aires. Slavery pushed down unskilled incomes or boosted those of positions requiring some skills.

This is a good example of a particular problem, which usually affects international living standard comparisons: the structural conditions of each economy have to be considered, especially when they involve labour costs. If attention is not paid to these conditions, comparative efforts will not provide purposive results. Moreover, it is worth stating that the longrun evolution of workers' purchasing power seems to be quite comparable. Workers in Montevideo and Rio Grande had gains between the 1770s and the first decade of the 1800s, which points to some degree of integration between the regional markets. Demographic research has shown that internal migration existed, although it was not so intense as to determine labour demand. Probably, more general processes played a major role; as the whole region benefited from cattle exports in the period, this resulted in similar pressures on labour demand in each city, which in turn contributed to similar evolutions of workers' purchasing power.

To summarise, we must stand out that useful comparisons must be developed using comparable data. To make baskets and salaries comparable across regions, they must belong to analogous categories and be composed of similar amounts of each food. A slight variation could lead to disparate results. In our opinion, questionable assumptions to fit the evidence should be avoided. In this article, we have sought to make regional comparisons, in order to offer a stronger evidence than the usual benchmark literature. In contrast with previous research, this article has attempted to find a better way to understand the differences, or at least to identify which changes in the structural features of a given economy could move living standards in one direction or another.

\section{CONCLUDING REMARKS}

This study presents, for the first time, a regional standards of living comparison, taking into account a region that shared, as a whole, one 
common characteristic: abundance of cattle and cheap relative value of meat, which was a strategic staple food and allowed the population to remain practically free of famine throughout its history. For this comparison, we have used data on southern Brazil, from 1772 to 1823 , taken from several sources, including the very rich hospital ledgers. Probate inventories complemented price series and salaries have been taken from construction works.

We discussed hospital records as a source for research on living standards and we have been able to identify the main components of real diets, segmented by ethnic, social or legal constraints. Our research presents three types of real baskets to show the consumption patterns of different social groups. We have calculated the caloric intake of each one of these baskets and also their respective monetary cost. We adapted these baskets to the methodology proposed by Allen (2001), seeking to offer new inputs for the literature, as well as to make a regional comparison.

From these estimates, we calculated welfare ratios using salaries from representative occupational categories. Our results showed positive ratios of the BBB even for the least qualified workers' categories. For the most complete baskets, coverage was positive only for the top skilled workers. Results presented here show that even in wartime situations (precisely at the dawn of independence in Latin America), living standards in southern Brazil do not seem to have undergone major changes.

We compare Rio Grande with the two main cities of the region: Buenos Aires and Montevideo. Results show a relative price stability at the end of the $18^{\text {th }}$ century, followed by a steady increase in food prices from the first years of the $19^{\text {th }}$ century. Tendencies were similar in the three cities but living standards in Rio Grande seem to have been higher than in the other two locations. We do not yet have enough data to build a definite explanation; however, our evidence stands that the structural labour conditions for the three cases have to be taken into account. Finally, an aspect to consider is that welfare ratio estimates under Allen's (2001) methodology have some problems that must be solved. In our comparison, the different composition of the baskets (much simpler in Rio Grande) leads to some distortion of the results. Thus, data should be collected, controlled and prepared very carefully to achieve this target. Finally, an aspect to consider is that Allen's (2001) methodology has some problems when data are not properly gathered or controlled to be applied to a given case study.

\section{ACKNOWLEDGEMENTS}

Received 31 January 2019. Accepted 17 December 2019.

This research was carried out with financial support from CONICET and ANPCYT, Argentina, through PIP 11220130100046CO and PICT 2017-4515 
projects and also with institutional support from the PPH-Historia, Universidade Federal de Rio Grande do Sul (Brazil). The authors thank María Inés Moraes for her comments on previous versions and the anonymous evaluators.

\section{REFERENCES}

AladRen, G. (2012): «Sem respeitar fé nem tratados: escravidão e guerra na formação histórica da fronteira sul do Brasil (Rio Grande de São Pedro, c. 1777-1835)». Niterói, Universidade Federal Fluminense, $\mathrm{PhD}$ thesis.

Allen, R.C. (2001): "The Great Divergence in European Wages and Prices From the Middle Ages to the First World War». Explorations in Economic History 38 (4), pp. 411-447.

Allen, R.C.; Murphy, T.E., and Schneider, E.B. (2012): «The Colonial Origins of the Divergence in the Americas: A Labor Market Approach». The Journal of Economic History 72 (4), pp. 863-894.

Allen, R.C.; Murphy, T.E., and Schneider, E.B. (2015): «Una de cal y otra de arena. Building Comparable Real Wages in a Global Perspective». Revista de Historia Económica/Journal of Iberian and Latin American Economic History 33 (1), pp. $61-75$

Arroyo-Abad, L.; Davies, E., and Van Zanden, J. L. (2012): «Between Conquest and Independence: Real Wages and Demographic Change in Spanish America, 1530-1820». Explorations in Economic History 49 (2), pp. 149-166.

Banzato, G. (2001) «Población y ocupación del espacio en la frontera del Salado. Chascomús, Monte y Ranchos entre 1815 y 1823». Trabajos y Comunicaciones 26/ 27, pp. 159-185.

BARICKMAN, B. (2003): Um contraponto baiano. Açúcar, fumo, mandioca e escravidão no Recôncavo, 1780-1860. Rio de Janeiro: Civilização Brasileira.

BeLL, S. (1993) «Early Industrialization in the South Atlantic: Political Influences on the Charqueadas of Rio Grande do Sul before 1860». Journal of Historical Geography 19 (4), pp. 399-411.

Berute, G. (2011). «Atividades mercantis do Rio Grande de São Pedro : negócios, mercadorias e agentes mercantis (1808-1850)». Porto Alegre, UFRGS, PhD thesis.

Challú, A., and Gómez-Galvarriato, A. (2015): "Mexico's Real Wages in the Age of the Great Divergence, 1730-1930». Revista de Historia Económica/Journal of Iberian and Latin American Economic History 33 (1), pp. 83-122.

Comadran Ruiz, J. (1969): Evolución demográfica argentina durante el período hispano (1535-1810). Buenos Aires: EUDEBA.

Comissoli, A. (2011): «À serviço da Sua Majestade: adiministração, elite e poderes no extremo meridional brasileiro, 1808-1831». Rio de Janeiro, Brasil, Universidade Federal do Rio de Janeiro, PhD thesis.

Costa Gomes, L. (2012): "Uma cidade negra: escravidão, estruturaeconômicodemográfica e diferenciação social naformação de Porto Alegre, 1772-1802». Universidad Federal de Rio Grande do Sul, Master's dissertation.

DJENDEREDJAan, J., and MARTIRÉN, J.L. (2015): «Precios, producto agrario y niveles de vida en las fronteras rioplatenses, 1700-1810: una nueva mirada sobre el crecimiento económico tardocolonial». Revista de Historia Económica/Journal of Iberian and Latin American Economic History 33 (1), pp. 123-152. 
Djenderedjan, J., and Martirén, J.L. (2016): «Measuring Living Standards. Some Caveats Concerning Salary Elements in Pre-modern Rio de la Plata Region, 1770-1830», Paper presented at International Conference Old and New Worlds: the Global Challenges of Rural History. Lisbon, 27-30 January 2016. Sociedad Española de Historia Agraria.

Dobado-GonZÁlez, R. (2015): «Pre-Independence Spanish Americans: Poor, Short and Unequal... or the Opposite?». Revista de Historia Económica/Joumal of Iberian and Latin American Economic History 33 (1), pp. 15-59.

Dobado, R., and García Montero, H. (2010): «Colonial Origins of Inequality in Hispanic America? Some Reflections Based on New Empirical Evidence». Revista de Historia Económica/Journal of Iberian and Latin American Economic History 28 (2), pp. 253 278.

Doursther, H. (1840): Dictionnaire Universel des Poids et Mesures anciens et modernes. Bruxelles: Imp. del'Académie Royale.

FrID, CARINA (2017): «Precios y crisis en una economía rioplatense. Santa Fe (17901850)». América Latina en la Historia Económica 24, pp. 59-92.

GARRIZ, C. (2012): «Rendimientos, peso, composición de res y cortesvacuos en la Argentina. Efectos del genotipo, edad y peso vivo de faena. ¿Producir carne con la raza criolla argentina?». Documento de Trabajo. Sitio Argentino de Producción Animal, Link: www.produccion-animal.com.ar.

Gelman, J., and Santilli, D. (2015a): «Salarios y precios de los factores en Buenos Aires, 1770-1880: Una aproximación a la distribución funcional del ingreso en el largo plazo». Revista de Historia Económical Joumal of Iberian and Latin American Economic History 33 (1), pp. 153-186.

Gelman, J., and SANTilLi, D. (2016): «Los estudios sobre el nivel de vida. La metodología de la canasta aplicada a la primera mitad del siglo XIX porteño». Folia Histórica del Nordeste 26, pp. 126-138.

Gelman, J., and Santilli, D. (2018): «Wages and Standards of Living in the 19th Century from a Comparative Perspective. Consumption Basket, Bare Bone Basket and Welfare Ratio in Buenos Aires, 1825-1849». Investigaciones de Historia Económica 14 (2), pp. 94-106.

GIL, T. (2009): "Coisas do Caminho: Tropeiros e seus negócios do Viamão a Sorocaba». Rio de Janeiro, PPGHIS/UFRJ, PhD thesis.

Johnson, H. (1973): «A Preliminary Inquiry Into Money, Prices and Wages in Rio de Janeiro, 1763-1823" in D. Alden (ed.), Colonial Roots in Modern Brazil. Berkeley: University of California Press, pp. 231-283.

Johnson, L. (1990): «Salarios, precios y costo de vida en el Buenos Aires colonial tardío». Boletín del Instituto de Historia Argentina y Americana. Dr Emilio Ravignani 2, pp. 133-157.

KüHn, F. (2006): «Gente da Fronteira. Família, Sociedade e Poder no sul da América Portuguesa, século XVIII». PhD thesis, Universidade Federal Fluminense, Rio de Janeiro.

Leitman, S. (1975), «O primeiro ciclo brasileiro de trigo e a guerra dos Farrapos». Revista do Insitututo Histórico e Geográfico Brasileiro 307 (abril-junho), pp. 58-74.

Lово, M. E. et al. (1971): «Evolução dos preços e dopadrão de vida no Rio de Janeiro, 1820-1930. Resultados preliminares». Revista Brasileira de Economia 25 (4), pp. $235-265$.

Luccock, J. (1820): Notes on Rio de Janeiro and the Southern Parts of Brazil; Taken during a Residence of Ten Years in that Country from 1808 to 1818. Londres: Pr. For Samuel Leigh. 
Matтoso, K. (1973): «Os preços na Bahia de 1750 a 1930», in CNRS (aa.vv), L'histoire quantitative du Brésil, 1800-1930. Paris: Centre National de la Recherche Scientifique, pp. 167-182.

Medeiros Dos Santos, C. (1984): Economia e Sociedade do Rio Grande do Sul. Século XVIII. São Paulo: Companhia Editora Nacional.

Moraes, M. I., and Thul, F. (2017): "Los salarios reales y el nivel de vida en una economía latinoamericana colonial: Montevideo entre 1760-1810». Revista de Historia Económica/Journal of Iberian and Latin American Economic History 36 (2), 185-213.

Moura, H. (2010): «Câmbio de longo prazo do mil-réis: uma abordagem empírica referente às taxas contra a libra esterlina e o dólar (1795-1913)». Cadernos de História 11 (15), pp. 9-34.

Namur, P., and Ferrando, C. (2007): «Rendimientos carniceros y su relación con las formas externas en bovinos criollos, británicos y suscruzas», Documento de Trabajo, Sitio Argentino de Producción Animal. Link: www.produccion-animal.com.ar

OsóRIo, Helen (1999): «Estancieiros, lavradores e comerciantes na constituição da Estremadura portuguesa na América. Rio Grande de São Pedro (1737-1822)». Universidade Federal Fluminense, Rio de Janeiro, PhD thesis.

Rodrigues, J. (2017): «De farinha, bendito seja Deus, estamos por agora muito bem": uma história da mandioca em perspectiva atlântica». Revista Brasileira de História 37 (75), pp. 69-95.

Saint Hilaire, A. (2002): [1887]. Viagem ao Rio Grande do Sul. Brasilia: Senado Federal.

Scotт, D. (2017). «A população do Rio Grande de São Pedro pelos mapas populacionais de 1780 a 1810». Revista Brasileira de Estudos de População 24 (3), pp. 617-633.

Torres, L. H. (2008): «A cidade do Rio Grande: escravidão e presence negra». Biblos 22 (1), pp. 101-117.

VARGAS, J. M. (2016): Os barões do charque e suas fortunas. Um estudo sobre as elites regionais brasileiras a partir de uma análise dos charqueadores de Pelotas (Rio Grande do Sul, século XIX). Sao Leopoldo: Oikos.

\section{APPENDIX}

\section{Data Sources}

The cost of living estimations corresponds to the vila of Rio Grande. However, in cases of absence of local prices, we cover this gap with market prices from Porto Alegre, the second port in importance of São Pedro do Rio Grande. This is not the best option, but a strong correlation between prices in both cities existed, so we considered this approach acceptable. In addition to its geographical proximity, Porto Alegre was a supply market with strong commercial connections with Rio Grande ${ }^{21}$.

21 About the economic evolution of São Pedro do Rio Grande and its mains ports (Rio Grande and Porto Alegre) during the late colonial period; see, among others, Medeiros dos Santos (1984), Osório (1999), Gil (2009), Berute (2011). 


\section{Prices}

- 1772: Meat, Farinha, Sugar, Rice, Soap and Candles. Arquivo Histórico do Rio Grande do Sul, Porto Alegre (AHRS, onwards), Fazenda, Maço 17, 1772, Diversosrecibos, Folha dos gastosfeitos no Hospital Real de São José do Norte do Rio Grande, Fev. 1772.

Bread: See Table A2

Cotton: Arquivo Histórico do Rio Grande do Sul, Porto Alegre (AHRS, onwards), Fazenda, Maço 17, 1772, Diversos recibos. Prices from Viamão, near Porto Alegre.

- 1792: Farinha, Sugar, Rice, Soap and Candles and Cotton. AHRS, Fazenda, Maço 37, Diversos Papeis. «Despesa diária feita no Hospital Real da Vila de São Pedro do Rio Grande», September-December 1792.

Meat: Due to the lack of meat prices for 1792, we made an estimation based on the relation of the price of cattle/arroba of meat, taken from sources of 1809 (8,33/1). We took prices of cattle from Arquivo Público do Rio Grande do Sul, Porto Alegre (APERS, onwards), Probate Records, 004.0782, Inv. Elisbão Machado; 004.0783, Inv. Manoel Bello da Silva (both from Triunfo, Comarca de Porto Alegre).

Bread: See Table A2

- 1802: Farinha, Bread, Sugar, Rice, Fat, Soap and Candles. AHRS, Fazenda, Maço 59, «Despeza com dietas». «Despesa diária feita no Hospital Real da Vila de São Pedro do Rio Grande», JanuaryNovember 1802.

Meat: As we do not have a price of meat for 1802, we estimated it based on the relation of the price of cattle/arroba of meat, taken from sources of 1809 (8,33/1). Once we had estimated the price of the Portuguese arroba ( 32 pounds of 0.46 kilograms), we proceeded to divide it by 32 , in order to get the retail price. We took prices of cattle from APERS, Inventários, 006.0375, Inv. Aguiar Peixoto and AHRS, Fazenda, Maço 63, Officios de Comm. Da Fronteira do Rio Grande.

Cotton: Market price data based on credit bills from APERS, Probate Records, 006.0375, Inv. Aguiar Peixoto, Rio Grande (Pelotas), 1802.

- 1809: Meat: Average market prices based on credit bills from APERS, Probate Records, 004.0804, Inv. Rosa Narcizo, Porto Alegre, 1809.

Farinha: Market price data based on credit bills from APERS, Probate Records, 005.0580, Inv. Jose Ferreira de Araujo, Rio Grande, 1809. Bread: See Table A2. 
Rice, Sugar and Cotton («Bayeta»): Average market prices based on credit bills from APERS, Probate Records, 005.0580, Inv. Vicente Ferreira dos Santos, Rio Grande, 1809.

Candles: Estimated through simple interpolation between prices of 1802 (already cited) and 1816 (APERS, Probate Records, 005.0583, Inv. Bibiana Maria Bandeira, Rio Grande, 1816).

- 1816: Meat: Average market prices based on credit invoices from APERS, Probate Records, 004.0815, Inv. Matias da Silveira e Souza, Porto Alegre, 1816.

Farinha: Average market prices based on private bills from APERS, Probate Records, 005.0584, Inv. Ma. Angélica Vasconcellos, Rio Grande, 1816.

Bread: See Table A2.

Rice, Sugar and Cotton ( Bayeta»): Average market prices based on private bills from APERS, Probate Records, 004.0816, Inv. Antonio Cabral, Porto Alegre; and 004.0800, Inv. Jerônymo Xavier de Azambuja, Porto Alegre, 1816.

Sugar and Cotton: Average market prices based on credit invoices from APERS, Probate Records, 005.0580, Inv. Vicente Ferreira dos Santos, Rio Grande, 1809.

Candles: Estimated through simple interpolation between prices of 1802 (already cited) and 1816 (APERS, Probate Records, 005.0583, Inv. Bibiana Maria Bandeira, Rio Grande, 1816).

- 1819: Meat: We used the same ratio cattle/meat as in 1802-benchmark year (8.33 arrobas de carne per cow/steer). Calculated from average cattle prices in Rio Grande and divided it by 8.33. The result was convergent. Average cattle prices of 1819 were taken from APERS, Probate Records, 005.0585, Inv. Antonio dos Santos Abreu, Rio Grande, 1819; 005.0586, Inv. João Batista Victo, Rio Grande, 1819.

Bread: As we find wheat price data equal to those of 1816, we assume that the price of bread would be the same.

Farinha, Rice, Sugar and Soap: Average market prices based on credit invoices from APERS, Probate Records, 005.0585, Inv. Antonio dos Santos Abreu, Rio Grande, 1819; 005.0586, Inv. João Batista Victo, Rio Grande, 1819.

Candles: Average market prices based on credit invoices from APERS, Probate Records, 004.0822, Inv. João Alves dos Santos, Porto Alegre, 1819. Cotton: Average market prices based on credit invoices from APERS, Probate Records, 005.0585, Inv. Antonio dos Santos Abreu, Rio Grande, 1819; 005.0586, Inv. Luiza Maria Joaquina, Rio Grande, 1819. 
- 1823: Meat: Average market prices based on credit invoices from APERS, Probate Records, 005.0587, Inv. Leonardo Germano, Rio Grande, 1823 and AHRS, Maço Unico, Feitoria do Linho Cánhamo, Relação do Estado da Feitoria, Porto Alegre, 1822.

Farinha: Average market prices based on credit invoices from AHRS, Autoridades Municipais, Câmara Municipal do Rio Grande, A.MU-168 and APERS, Probate Records, 005.0587, Inv. Leonardo Germano, Rio Grande, 1823.

Rice: Average market prices based on credit bills from APERS, Probate Records, 005.0587, Inv. Leonardo Germano, Rio Grande, 1823; 004.

Sugar, Soap and Cotton: Average market prices based on credit bills from APERS, Probate Records, 005.0587, Inv. Leonardo Germano, Rio Grande, 1823; 004.0146, Inv. Antonio J. de Britto, Porto Alegre, 1823.

Candle: Due to the lack of data for 1823-benchmark year, we used data corresponding to 1822. In APERS, Probate Records, 005.0587, Inv. Leonardo Germano, Rio Grande, 1823.

\section{Wages}

- 1772: Carpenters (Official and Serventes or Labourers): Average daily wages in AHRS, Fazenda, Maço 17, Diversos Papeis, Rio Grande, 1772.

- 1792: Carpenters (Official and Serventes or Labourers): Average daily wages in AHRS, Fazenda, Maço 35, Folhas de despesas, Porto Alegre, 1792; and AHRS, Fazenda, Maço 41, Diversos Papeis, Rio Grande, 1792.

Masons (Official and Serventes or Labourers): APERS, Probate Records, 004.0782, Inv. João Vicente Neiva, Porto Alegre, 1792.

- 1816: Carpenters (Officials): Average daily wages in APERS, Probate Records, 004.0820, Inv. João Antonio Dias, Porto Alegre, 1816.

Carpenters (Officials) and Masons (Official and Serventes or Labourers): Average daily wages in APERS, Probate Records, 004.0820, Inv. João Antonio Dias, Porto Alegre, 1816.

- 1819: Carpenters (Officials): Two wage records in APERS, Probate Records, 004.0823, Inv. Manoel Ignacio Rodrigues, Porto Alegre, 1819.

Masons (Official and Serventes or Labourers): Average daily wages in APERS, Probate Records, 005.0584, Inv. Manoel Joaquim de Andrade, Rio Grande, 1819. 
Table A1

RELATIVE WEIGHT IN CALORIC AND MONETARY TERMS OF EACH FOOD PURCHASED BY THE MILITARY HOSPITAL OF RIO GRANDE, 1792-1803

\begin{tabular}{|c|c|c|c|c|c|c|c|c|c|c|c|c|}
\hline \multirow[b]{2}{*}{ Year } & \multicolumn{2}{|c|}{ Fresh meat } & \multicolumn{2}{|c|}{ Farinha } & \multicolumn{2}{|c|}{ Bread } & \multicolumn{2}{|c|}{ Rice } & \multicolumn{2}{|c|}{ Sugar } & \multicolumn{2}{|c|}{ Others } \\
\hline & $\begin{array}{l}\% \text { of total } \\
\text { purchases }\end{array}$ & \begin{tabular}{|l|}
$\begin{array}{l}\% \\
\text { of } \\
\text { total } \\
\text { calories }\end{array}$ \\
\end{tabular} & $\begin{array}{l}\% \text { of total } \\
\text { purchases } \\
\end{array}$ & \begin{tabular}{|l|}
$\%$ of \\
total \\
calories
\end{tabular} & $\begin{array}{l}\% \text { of total } \\
\text { purchases }\end{array}$ & \begin{tabular}{|l|}
$\begin{array}{l}\% \text { of } \\
\text { total } \\
\text { calories }\end{array}$ \\
\end{tabular} & $\begin{array}{l}\% \text { of total } \\
\text { purchases }\end{array}$ & \begin{tabular}{|l|}
$\begin{array}{l}\% \text { of } \\
\text { total } \\
\text { calories }\end{array}$ \\
\end{tabular} & $\begin{array}{l}\% \text { of total } \\
\text { purchases }\end{array}$ & \begin{tabular}{|l|}
$\begin{array}{l}\% \text { of } \\
\text { total } \\
\text { calories }\end{array}$ \\
\end{tabular} & $\begin{array}{l}\% \text { of total } \\
\text { purchases }\end{array}$ & \begin{tabular}{|l|}
$\%$ of \\
total \\
calories
\end{tabular} \\
\hline 1792 & $12 \%$ & $33 \%$ & $0 \%$ & $0 \%$ & $58 \%$ & $50 \%$ & $12 \%$ & $5 \%$ & $17 \%$ & $8 \%$ & $1 \%$ & $4 \%$ \\
\hline 1793 & $12 \%$ & $35 \%$ & $5 \%$ & $6 \%$ & $51 \%$ & $43 \%$ & $13 \%$ & $5 \%$ & $15 \%$ & $6 \%$ & $4 \%$ & $5 \%$ \\
\hline 1794 & $12 \%$ & $34 \%$ & $15 \%$ & $18 \%$ & $40 \%$ & $31 \%$ & $18 \%$ & $7 \%$ & $8 \%$ & $3 \%$ & $7 \%$ & $6 \%$ \\
\hline 1795 & $7 \%$ & $26 \%$ & $6 \%$ & $9 \%$ & $43 \%$ & $45 \%$ & $24 \%$ & $9 \%$ & $12 \%$ & $6 \%$ & $8 \%$ & $4 \%$ \\
\hline 1796 & $10 \%$ & $34 \%$ & $12 \%$ & $16 \%$ & $35 \%$ & $34 \%$ & $19 \%$ & $8 \%$ & $14 \%$ & $7 \%$ & $10 \%$ & $2 \%$ \\
\hline 1797 & $9 \%$ & $31 \%$ & $8 \%$ & $12 \%$ & $41 \%$ & $42 \%$ & $22 \%$ & $7 \%$ & $12 \%$ & $6 \%$ & $8 \%$ & $3 \%$ \\
\hline 1798 & $6 \%$ & $23 \%$ & $6 \%$ & $10 \%$ & $44 \%$ & $50 \%$ & $23 \%$ & $8 \%$ & $12 \%$ & $7 \%$ & $9 \%$ & $3 \%$ \\
\hline 1799 & $17 \%$ & $46 \%$ & $13 \%$ & $15 \%$ & $32 \%$ & $25 \%$ & $32 \%$ & $8 \%$ & $1 \%$ & $0 \%$ & $6 \%$ & $6 \%$ \\
\hline 1800 & $24 \%$ & $51 \%$ & $17 \%$ & $18 \%$ & $24 \%$ & $15 \%$ & $23 \%$ & $6 \%$ & $1 \%$ & $0 \%$ & $10 \%$ & $9 \%$ \\
\hline 1801 & $14 \%$ & $40 \%$ & $11 \%$ & $16 \%$ & $29 \%$ & $24 \%$ & $32 \%$ & $7 \%$ & $3 \%$ & $1 \%$ & $12 \%$ & $12 \%$ \\
\hline 1802 & $8 \%$ & $30 \%$ & $10 \%$ & $18 \%$ & $29 \%$ & $30 \%$ & $31 \%$ & $7 \%$ & $4 \%$ & $2 \%$ & $18 \%$ & $13 \%$ \\
\hline 1803 & $10 \%$ & $29 \%$ & $12 \%$ & $17 \%$ & $41 \%$ & $35 \%$ & $25 \%$ & $7 \%$ & $2 \%$ & $1 \%$ & $11 \%$ & $12 \%$ \\
\hline
\end{tabular}

Notes: Methodologically, we converted the volumes of annual purchases of each food into calories, in order to estimate the caloric weight of each good over the total purchases. For caloric estimations we have used equivalences present in similar foods today, assuming that it is difficult that there have been really substantial changes in them. Most of the caloric values were taken from the web http://www.myfitnesspal.com/es/food/calories/, based on the data provided by consumers, and the standard references presented in the nutrient database from the United States Department of Agriculture (USDA), at https:/ ndb.nal.usda.gov/ndb/search/list. Other data were taken from the information offered by the manufacturers in the respective packages.

Source: Calculated with information based on monthly data of expenses of the Military Hospital of Rio Grande between 1792 and 1803 . AHRS, Fazenda, Maços 37-64, already cited in Data Sources section. 
Figure A1

WEIGHT OF EACH COMPONENT IN TOTAL EXPENDITURE. MILITARY HOSPITAL, RIO GRANDE.

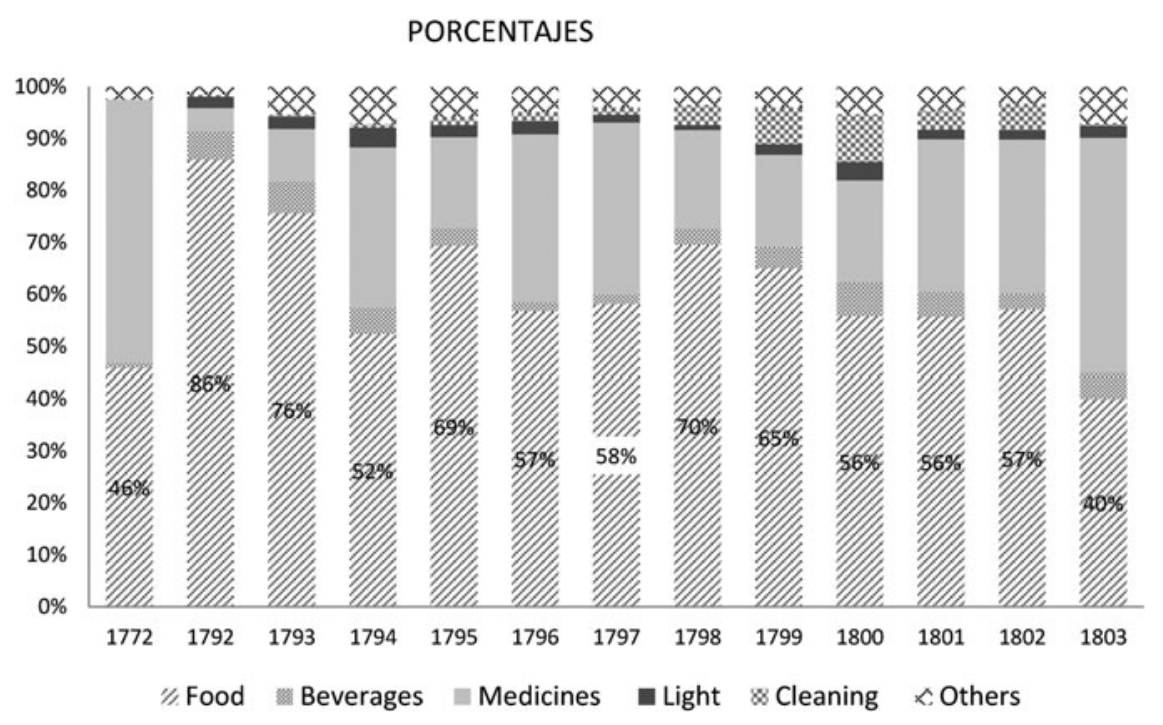

Source: Table A1.

- 1823: Carpenters and Masons (Official and Serventes or Labourers): Average daily wages in APERS, Probate Records, 005.0584, Inv. Manoel Joaquim de Andrade, Rio Grande, 1823.

\section{Methodological Notes}

\section{Calories Estimations}

It is very difficult to estimate the caloric power of meat, since we are not certain about what kind of cuts the population took advantage of. Analysing the sources, there are no obvious differences between the cuts, since this product always appears as "meat». If we look to qualitative sources, such as the testimony of the traveller Saint Hilaire, it has to be assumed that the meat consumed was highly caloric, since it refers to the consumption of the fattest parts of the animal. However, other sources do not follow this logic. For example, the tax per arroba of meat slaughtered in the abattoir (Açougue) of Rio Grande and established by the Real Fazenda in 1809 did not discriminate by particular cuts but taxed all the arroba of meat slaughtered equally. Although, in some occasions, it gave account of the variable quality of the meat implying that there 
Table A2

WHEAT (IN ALQUEIRES, SECONDARY AXIS), FLOUR AND BREAD PRICES (IN POUNDS, PRIMARY AXIS). PRICES EXPRESSED IN LOCAL CURRENCY (REIS)

\begin{tabular}{|l|c|c|c|}
\hline & $\begin{array}{l}\text { Wheat } \\
\text { (Alqueire) }\end{array}$ & $\begin{array}{l}\text { Wheat } \\
\text { flour } \\
\text { (Pound) }\end{array}$ & $\begin{array}{c}\text { Bread } \\
\text { unit } \\
\mathbf{( 1 . 2 5} \\
\text { pounds) }\end{array}$ \\
\hline $1771-1775$ & 935 & 80 & 39.5 \\
$1776-1780$ & - & - & - \\
$1781-1785$ & - & - & - \\
$1786-1790$ & - & - & - \\
$1791-1795$ & 970 & 84 & 40.6 \\
$1796-1800$ & 1,125 & 93.5 & 45.5 \\
$1801-1805$ & 1,330 & 99.6 & 52 \\
$1806-1810$ & 990 & - & 41.5 \\
$1811-1815$ & 1,107 & - & 44.9 \\
$1816-1820$ & - & - & - \\
$1821-1825$ & - & - & 65.5 \\
$1826-1830$ & 1,760 & 160 & - \\
\hline
\end{tabular}

Source: Calculated from data on exports taken from (Leitman 1975, p. 74), and current wheat prices, taken from official sources of AHRS (Fazenda) and particular commercial accounts in diverse probate inventories, Rio Grande, Rio Pardo, Triunfo and Porto Alegre. AHRS, Estatística, Maços 43, 64, 74, 519 and APERS, Boxes 006.0375; 004.0800; 004.0804; 005.0579; 005.0580; 007.0250; 007.0254. Wheat flour prices in pounds were taken from Military Hospital records. AHRS, Fazenda, Maços 37 a 64.

was a big difference in the slaughtered animals, surely by seasonal questions: "It is necessary to note that the meat from the month of September and October [1809] was extremely thin; in both abattoirs [Rio Grande and São Jose do Norte], people turned to fish; and others ... picked cattle from their Estancias.» AHRS, Fazenda, Maço 83, 3 November 1809. Given this difficulty, we opted for applying a caloric value to meat taking into account the yields of Creole cattle offered by Namur and Ferrando (2007, pp. 1-2). According to them, the slaughter performance of the Creole breed is estimated at 57 per cent of live weight. However, our idea is to approach the possible real consumption of this product, so to calculate the caloric value, we also removed from the cut the proportion of bone and external fat (18 and 14 per cent, respectively, according to the source). So, to calculate the caloric average of the meat, which was 210 calories, we subtract 32 per cent and reach to an estimate of its net caloric value: 143 calories. This value has been applied to the total of the meat offered in each diet. Data are also offered in Garriz (2012). 


\section{Methodological Note}

Food includes bread, wheat flour, sugar, butter, salt, fat, vinegar, eggs, milk, rams, young female bovines and marmalade. Beverages include wine and spirits. Medicines include hens and chickens (for purges) and bloodlettings. Light includes tallow candles. Cleaning includes soap and laundry. Others include various administrative expenses (paper, ink), imported goods (wine from Porto, olive oil) and many others required for daily use (clothes for shrouds, etc.).

\section{Methodological Note}

The bread weight calculation has been made based on a 1781 source, in which the military authorities account for the supply of one of the city bakers. There, they explain that each alqueire of wheat yielded forty-eight bread pieces of five quarters of a Portuguese pound (115 grams each quarter). So assuming that the wheat alqueire of the time weighed 60 pounds, we conclude that the bread had 575 grams (or almost 20 ounces, a similar value for the Rio de la Plata). Anyway, it is likely that this unit has not been uniform over time, if we take into account that we have not found alterations in the price of bread over the years analysed. Therefore, it is likely that in the face of sudden changes in the price of wheat, adjustments would be made on the weight of bread, and not on its monetary price. See AHRS, Fazenda, Maço 69, Reqs. à Junta, Nro. 28. Flour yield of wheat taken from a note in the Gazeta de Lisboa, Portugal, Nro. VII, 19 March 1805, «Direcção para fazer pão caseiro». 